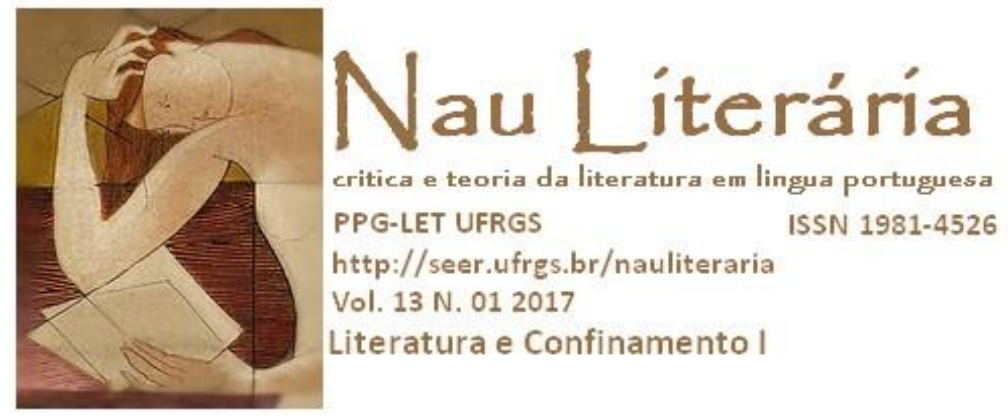

\title{
A construção das identidades pós-modernas em Teoria geral do esquecimento, de José Eduardo Agualusa
}

\section{João Marcos Dadico Sobrinho}

Resumo: Este trabalho se dispõe a analisar a construção das personagens do romance Teoria geral do esquecimento (2012), de José Eduardo Agualusa, pela perspectiva da metaficção historiográfica, como definido pela teórica canadense Linda Hutcheon. Uma análise bibliográfica apoiada nos conceitos dessa teórica e de Stuart Hall sobre as identidades pós-modernas ajudam no entendimento de como o romance é constituído a partir das relações de interdependência existentes entre as diversas personalidades "ex-cêntricas" que o compõem, o que possibilita ao leitor uma crítica sobre a importância dos sujeitos para a construção da história recente de Angola (século XX e XXI) e para a construção de uma realidade mais solidária no presente.

Palavras-chave: José Eduardo Agualusa; Literatura Africana; Metaficção Historiográfica.

\begin{abstract}
This paper sets out to analyze the characters construction in the novel Teoria geral do esquecimento (2012), by José Eduardo Agualusa, from the perspective of Historiographical Metafiction, as defined by the Canadian theoretical Linda Hutcheon. A bibliographic analysis supported on the concepts of this theoretical and Stuart Hall's about the post-modern identities helps in understanding how the novel is constituted from the existing interdependencies between the various "ex-centric" personalities that compose it, which allows to the reader a review about the importance of subjects for the construction of recent history of Angola (XX and XXI century) and for the establishment of a more cohesive reality nowadays.
\end{abstract}

Keywords: José Eduardo Agualusa; African Literature; Historiographical Metafiction.

O pós-modernismo nos ensina que todas as práticas culturais têm um subtexto ideológico que determina as condições da própria possibilidade de sua produção ou de seu sentido. E na arte ele o faz deixando visíveis as contradições entre sua autorreflexividade e sua fundamentação histórica. (HUTCHEON, 1991, p. 15)

\section{Introdução}

José Eduardo Agualusa é um desses prodígios da contemporaneidade. O jornalista, natural de Huambo, tem mais de trinta e três livros publicados, desde 1989, quando lançou o livro A conjura. Sua obra é extensa e variada, e chama a atenção de parte da crítica literária a partir da publicação dos livros Estação das chuvas (1996) e O vendedor de passados (2006). 
Traduzidos em várias línguas, esses dois romances tangenciam seus enredos na presença e na importância da História de Angola para a construção das personagens, como forma de estabelecer uma crítica à própria construção das identidades angolanas.

Apenas para exemplificar alguns recentes trabalhos sobre a obra desse autor, Ana Cristina Bezerra, em sua dissertação de mestrado A tessitura da memória em O Vendedor de Passados, de José Eduardo Agualusa (2013), afirma que no romance de Agualusa “o campo das certezas diante da própria noção de realidade e fantasia está suspenso e há até mesmo uma 'transferência de sentidos' entre esses universos" (BEZERRA, 2013, p. 82). Juan Filipe Stacul, em seu artigo Um homem em busca de memória, um povo em busca de identidade: as relações entre literatura e história no romance o vendedor de passados, de José Eduardo Agualusa, explica que:

\begin{abstract}
As relações entre literatura, história e memória apresentam-se na literatura africana, sobretudo na criação literária contemporânea, de modo bastante significativo. Os autores africanos contemporâneos encontraram na criação artística uma forma de resgatar valores culturais silenciados no período de colonização e legitimar a identidade do povo africano. A forma como o discurso histórico e o ficcional se configuram nessas obras, no entanto, apresenta um distanciamento muito tênue entre o "real" e o "inventado". (STACUL, 2010, p. 264)
\end{abstract}

Agualusa é um "criador de passados": quando ele apresentou as histórias de Lídia do Carmo Ferreira e Félix Ventura ao mundo, apresentou também toda uma perspectiva da literatura angolana pós-modernista ${ }^{1}$. As consequências da Revolução de Independência e da Guerra Civil de Angola ainda estão presentes na lembrança dessa jovem nação e são de imensa relevância para o entendimento da complexa formação das identidades contemporâneas do povo angolano. Por exemplo, Nelson Pestana escreve no capítulo "A história na estória: Henrique Abranches e José Eduardo Agualusa", do livro Marcas da Diferença: as literaturas africanas de língua portuguesa (2006), organizado por Rita Chaves e Tania Macêdo, que, na esperança de responder a algumas lacunas desse doloroso passado, através do romance Estação das Chuvas,

[Agualusa situa-se], ele próprio, no tempo histórico que pretende ver tratado, melhor dizendo discutido, para colocar as questões que este tempo histórico, do seu ponto de vista, não soube abordar, ou não soube resolver, ou simplesmente para dar a conhecer a face oculta das figuras míticas da nossa história recente. (PESTANA, 2006, p. 233)

\footnotetext{
${ }^{1}$ Usaremos o termo por se tratar de uma questão artística; o pós-moderno é uma questão histórica, filosófica, mais ampla, e a distinção entre os dois é necessária.
} 
Romances dessa categoria revelam traços da "poética" pós-modernista literária, como definida por Linda Hutcheon (1991). Teoria geral do esquecimento (2012) é o romance no qual se aprofundam as relações entre a prosa de Agualusa e as poéticas pós-modernistas contemporâneas da literatura, sobretudo a "metaficção historiográfica". Inclusive, ao constatar que uma das "estratégias de representação" (HUTCHEON, 1991, p. 14) utilizadas pelo autor na sua escrita pós-modernista é a inserção de personalidades instáveis, que se transformam durante o desenvolvimento do enredo, através das inter-relações diretas e indiretas estabelecidas entre si, de forma a enquanto se modificam, gradativamente, modificam também as estruturas em que estão inseridas. Esse movimento de transformação das personalidades revela como os complexos descentramentos das identidades pós-modernas, como sintetizados por Stuart Hall (2011), podem contribuir na constituição das personagens dos romances pósmodernistas. A necessidade das metaficções historiográficas de questionar a história a partir dos "discursos minoritários 'ex-cêntricos' que [as] modelaram" (HUTCHEON, 1991, p. 1314 - grifo meu) se concretiza, em Teoria geral do esquecimento, nas histórias de uma mulher que se isola do mundo, de um perseguido político que encontra diamantes dentro de um pombo e de um jornalista colecionador de desaparecimentos. Através das histórias dessas personagens, que se transformam e, ao mesmo tempo, modificam o mundo a sua volta, Agualusa apresenta um romance sensível, contundente e com o claro objetivo de incentivar o leitor à crítica dos sistemas totalizantes contemporâneos.

A definição dessa "teoria" (conceito presente no título do romance) é o desafio que o título do romance propõe ao seu leitor, pois ao se descobrir como "aprender a esquecer", ele (o leitor) será conduzido a uma reflexão mais profunda sobre a história de Angola e a construção das identidades angolanas. A necessidade de complementar o conhecimento sobre a história angolana durante a leitura do romance permite ao leitor mais atento, também, ampliar a sua compreensão dessa "história oficial". A partir da reconstituição de acontecimentos históricos "vividos" por diferentes subjetividades pós-modernas, inclusive aquelas marginalizadas (ex-cêntricas), que são demonstradas como interdependentes tanto da história quanto entre si, o leitor é instigado, justamente, a perceber que essas relações sociais, que exemplificam o "estudo" sobre o "esquecimento" do autor, podem complementar as informações correntes sobre passado angolano, posto que este é ainda incompleto, cheio de mistérios e repleto de chagas abertas pelas hegemonias políticas estrangeiras, que influenciaram o processo de independência e a guerra civil. O passado precisa ser "lembrado" para reforçar a necessidade de "esquecê-lo", pois somente dessa forma as novas identidades 
gestadas durante os conflitos históricos poderão conviver em um presente mais solidário e mais consciente.

Esse argumento de "lembrança" e "esquecimento" voluntários, que o romance Teoria geral do esquecimento evoca, em muito se aproxima dos argumentos de Antonio Candido sobre a constituição da literatura brasileira modernista, e que Benjamin Abdala Jr. entende como influência complementar da literatura angolana. Uma mistura de aceitação e recusa à literatura da metrópole, que Mia Couto explica em seu livro Pensatempos (2004):

[...] Os brasileiros já se davam ao luxo do esquecimento. Mas essa desmemoria não era possível no moçambicano. Moçambique era ainda uma colônia. Era preciso ser-se <<contra〉>. Como encontrar na escrita uma arma grávida de futuro? Pedia-se um novo encontro, um alimento para ganhar força e esperança para mover a História [...] Desta feita, foram autores como Graciliano Ramos, Jorge Amado, Raquel de Queiroz e poetas como Drummond de Andrade e João Cabral de Melo Neto que serviram de inspiração. Moçambique bebia da alma de outro continente. (COUTO, 2004, p. 105)

Outros possíveis desdobramentos críticos dessa "tese" aproximam o romance ainda de uma análise pós-colonialista, que situaria o discurso do autor no "entre-lugar" da literatura latinoamericana, de Silviano Santiago, onde "o artista latinoamericano aceita a prisão como forma de comportamento, a transgressão como forma de expressão" (SANTIAGO, 1978, p. 27). Contudo, todo o enredo é assumidamente ficção, ainda que apoiado diretamente na história angolana; a discussão filosófica da memória que paira no romance não conduz este ao gênero memorialista. Nesse romance, a memória é ainda ficção, e tem o claro objetivo da verossimilhança. E, com mais ênfase, localizam-se, nas "reminiscências" das personagens do romance, ações inerentes aos complexos descentramentos das identidades pós-modernas. Completamente interligadas pelas estruturas sociais e culturais, essas identidades têm a história como determinante para a sua formação; porém, conforme essas identidades se deslocam no tempo, adaptam-se e acabam por aprenderem a também influenciar a própria história, a partir do presente. Algo que pode surpreender o leitor, não apenas porque são transformações subjetivas profundas, mas também porque são transformações com grande alcance social, que expõe as complexas redes cooperativas estabelecidas entre as personagens.

Ainda que estas personagens estejam excluídas do centro das discussões políticas da nação, cada uma delas é necessária para a sobrevivência da outra, mesmo que indiretamente, pois todas elas estão conectadas pelas consequências de suas ações. São essas histórias excluídas, ou esquecidas propositadamente do discurso histórico (off-centro), que são realmente capazes de esclarecer, ou pelo menos sugerir alguma verdade ainda oculta sobre a história de Angola e sobre a constituição dessas identidades. Carregado desse propósito, o 
romance aproxima-se da metaficção historiográfica na medida em que incita ao leitor uma "autoconsciência sobre a história e a ficção como criações humanas (metaficção historiográfica)", que "passa a ser a base para seu repensar e sua reelaboração das formas e dos conteúdos do passado" (HUTCHEON, 1991, p. 22).

A metaficção historiográfica, enquanto uma poética literária típica do pósmodernismo, permite que se aproxime a análise da construção das identidades do romance, com a análise dos descentramentos das identidades pós-modernas, com viés para a crítica, a partir dos fatos históricos estruturais, que são definitivos para a constituição dessas personagens.

\section{A metaficção historiográfica como poética literária em Teoria geral do esquecimento}

Se em Estação das chuvas os fatos relativos à independência de Angola são reconstruídos através das entrevistas concedidas ao narrador pela escritora Lídia do Carmo Ferreira, e, em $O$ vendedor de passados, a transição das personagens ao novo regime democrático obriga as pessoas a comprar "novos passados", em Teoria geral do esquecimento os "fatos" da história angolana que estruturam as identidades das personagens, especialmente aqueles relativos aos conflitos pós-independência, complementam esse cenário histórico já desenhado anteriormente por esses dois romances do autor, em direção à contemporaneidade. A forma como cada uma das personagens deve esquecer dos conflitos vividos para aprender, então, a se relacionar pacificamente com seus semelhantes são reflexões às quais a "tese" do autor conduz.

Esse tipo de literatura, que se propõe como roman à thèse, mas que apresenta "mais um entre os discursos pelos quais elaboramos nossas versões da realidade" (HUTCHEON, 1991, p. 64), é característica do pós-modernismo. Segundo Linda Hutcheon (1991), a metaficção historiográfica se dirige às

[...] questões como as da forma narrativa, da intertextualidade, das estratégias de representação, da função da linguagem, da relação entre o fato histórico e o acontecimento empírico, e, em geral, das consequências epistemológicas e ontológicas do ato de tornar problemático aquilo que antes era aceito pela historiografia - pela literatura - como uma certeza. (HUTCHEON, 1991, p. 14)

A presença de personagens "ex-cêntricas" (ou "off-centro", "inevitavelmente identificado com o centro ao qual aspira, mas que lhe é negado" (HUTCHEON, 1991, p. 88)) é outra característica da metaficção historiográfica. A história é toda contada sob o ponto de 
vista de personagens alijadas do discurso histórico oficial, criando-se, assim, uma reflexão sobre a verdade dos acontecimentos históricos. Tanto nas teorias, quanto nas práticas do pósmodernismo têm-se "mostrado maneiras de transformar o diferente, o off-centro, no veículo para o despertar da consciência estética e até mesmo política - talvez o passo primeiro e necessário para qualquer mudança radical” (HUTCHEON, 1991, p. 103).

O romance conta a história de Ludovica Fernandes Mano, uma portuguesa de Aveiro que se mudou para Luanda antes da Independência de Angola. Um dia após os eventos revolucionários, sua irmã e seu cunhado somem. Sozinha e com um cão, ela é obrigada a lutar pela sua sobrevivência. Após uma tentativa de assalto, que culminou com a personagem alvejando o assaltante com o revólver do cunhado, ela decide erguer um muro entre a porta do apartamento e o corredor do prédio. Isolada, ela e seu cão, Fantasma, tentam encontrar meios para sobreviver, e ela para continuar sã. Porém, Ludo, durante a clausura e após sua libertação por um órfão, Sabalu, alcança a percepção de como suas ações podem influenciar, decisivamente, a vida de outras pessoas, que ela nem conhecia. Por ser uma mulher, portuguesa, enclausurada, nesse momento de guerra Ludovica está completamente impossibilitada de exercer direitos ou participar ativamente de qualquer ação política concreta. Ela pertence àqueles grupos considerados "minoritários", excluídos das decisões macrossociais, mas que ainda assim buscam se expressar ou serem, no mínimo, representados. Essa é outra perspectiva da personagem ex-cêntrica, ela também busca uma relação direta com o centro das decisões sociais, mas, por qualquer motivo, não pode exercer essa relação.

O romance de Agualusa também pode revelar-se autorreflexivo, outra característica da metaficção historiográfica. Na "Nota Prévia" do livro (AGUALUSA, 2012, p. 7), o narrador explica que teve acesso aos diários, poesias e fotos das paredes do apartamento em que a protagonista esteve enclausurada, todas escritas a carvão pela protagonista, em razão do longo período de isolamento. Tal procedimento é uma tradicional ferramenta de verossimilhança utilizada pelo autor para lhe conferir alguma legitimidade. A relação entre realidade e ficção são artifícios do autor para estabelecer o jogo metaficcional. Para a metaficção historiográfica, contudo, não basta a "reconstituição biográfica" de uma personagem "ex-cêntrica" autoconsciente. É preciso que outros elementos resultantes do processo histórico sejam introduzidos, para, assim, ampliar a perspectiva do leitor.

A ação de clausura de Ludovica é uma resposta dessa personagem para acontecimentos muito particulares da história angolana. Após a falha dos "Acordos de Alvor" para a transição do governo colonial ao governo popular angolano (VISENTINI, 2012), a 
disputa pelo poder de Angola se intensifica de tal forma que o Movimento Pela Libertação de Angola (MPLA), a Frente Nacional pela Libertação de Angola (FNLA) e a União Nacional de Independência Total de Angola (UNITA) iniciam confrontos armados. Enquanto a MPLA é apoiada pelo bloco Leste comunista (URSS e Cuba), a FNLA é apoiada pelas potências ocidentais, pelo Zaire e pela China (após o rompimento desta com a URSS) e a UNITA tem o apoio da África do Sul.

Durante a clausura, mesmo diante do desespero e do isolamento, a personagem consegue se relacionar com o limitado mundo à sua volta, para se tornar parte dele, alterandoo, deformando-o e construindo uma nova existência - harmônica, ainda que restrita. Em momentos de extrema fome e com estoque racionado de alimentos, Ludo se pôs a caçar pombos para si e para Fantasma. Ela se utilizava de diamantes como isca da arapuca, diamantes estes que achara escondidos embaixo do colchão de Orlando. Assim, Ludo encontrou um pombo-correio com um bilhete de amor preso à pata. Comovida pela fantasia de uma história de amor, ela liberta o pombo com o diamante no papo, chega a pensar em indicar a pequena fortuna na carta, mas se contenta em sonhar com um amor realizado, na felicidade de ter colaborado com alguém. O pombo-correio, contudo, é caçado por outra personagem, que tem sua vida completamente transformada pelo dinheiro da venda dessas pedras encontradas no papo do pombo-correio.

Essa é a crítica mais ferrenha do narrador ao contexto histórico gerador da realidade angolana. Uma realidade crítica, ampliada pela multiplicidade de pontos de vista, que as personagens Pequeno Soba, Monte, Daniel Benchimol e Nasser Evangelista estabelecem entre si e com a protagonista do romance, Ludovica. Todos eles se relacionam direta ou indiretamente por motivos diversos, mas definidos pelo momento histórico em que estavam inseridos. Nasser Evangelista, por exemplo, fora acusado de ser "fraccionista" pelo noivo de uma enfermeira pela qual se enamorara, fora preso e, depois, destacado como enfermeiro na prisão, onde Pequeno Soba também era prisioneiro. Nasser acompanhou todos os martírios que Monte empreendeu em Pequeno Soba e, revoltado, elaborou o plano para falsificar a morte de Pequeno Soba e contrabandeá-lo para fora da prisão dentro de um caixão. Vida e morte se misturam na história de Pequeno Soba, que passou de pequeno burguês a esquerdista radical e, por fim, a pequeno burguês novamente. Vida e morte de suas ideologias, vida e morte para alcançar a liberdade.

Arnaldo Cruz, ou Pequeno Soba, é um angolano nato. Tinha uma expectativa de vida burguesa e tranquila, mas "quando todos esperavam vê-lo ingressar na faculdade e virar doutor, meteu-se em sarilhos políticos e foi preso" (AGUALUSA, 2012, p. 53-54). Logo na 
primeira vez em que foi preso, foi ajudado por um enfermeiro, Nasser Evangelista, que chegou a falsificar um atestado de óbito e traficou-o dentro de um caixão. Para escapar da polícia política fingia-se de louco. "Passou, assim, a circular pelas ruas, andrajoso, coberto de lama e alcatrão" (AGUALUSA, 2012, p. 54) na tentativa de fugir do MPLA, permanecendo onde eles jamais procurariam, à vista de todos. Na busca por alimento, caçou um pombocorreio, que curiosamente continha dois diamantes em seu papo e uma mensagem presa à pata: "Amanhã. Seis horas, lugar habitual. Muito cuidado. Amo-te" (AGUALUSA, 2012, p. 55). Com um entendimento de que a providência divina estava lhe dando um sinal, fora para a frente da Livraria Lello, seu lugar habitual. Foi neste lugar que Madalena, uma enfermeira, percebeu a sanidade deste, e chamou-o a ser caseiro na sua chitaca ${ }^{2}$ e ajudá-lo. Após todos esses eventos, Monte prende Madalena e Pequeno Soba novamente, por motivo de uma investigação que fazia sobre o paradeiro do mercenário Jeremias Carrasco.

Pequeno Soba escapa pela segunda da vez da prisão por advento do 27 de maio de 1977. Essa data marcou o levante Fraccionista do MPLA, membros do governo aliados a Nito Alves, com ideologia comunista radical, levantaram-se contra o abrandamento da política socialista de Agostinho Neto e puseram-se a soltar todos os presos políticos. Mesmo livre, Pequeno Soba foi reconhecido pela polícia, que o perseguiu até um beco e o colocou num camburão. O veículo fora abalroado por um caminhão e, mais uma vez, o Pequeno Soba pôde fugir, mas foi com a ajuda de Papy Bolingô que, definitivamente, alcançou a liberdade. Ludovica assistiu ao episódio da fuga de Pequeno Soba na sacada da cobertura em que se encontrava enclausurada. Graças aos diamantes do pombo-correio, Pequeno Soba pôde iniciar um negócio de entregas, que prosperou. Daí em diante, dedicou-se a vários outros empreendimentos, inclusive filantrópicos, pacificamente, realizando o seu destino como mais do que um típico burguês angolano.

Papy Bolingô era um radialista da Rádio Nacional, que por advento do 27 de maio fora demitido. Enquanto ia caminhando pelas ruas, deparou-se com o acidente de um caminhão e um camburão e com um homem preso em algemas a correr para a liberdade. Como por instinto ajudou aquele homem e conduziu-o para o seu apartamento; foi assim que conheceu Pequeno Soba. Enquanto usava suas habilidades circenses para abrir as algemas do novo amigo, ouvia no rádio: "É preciso encontrá-los, amarrá-los e fuzilá-los" (AGUALUSA, 2012, p. 59, grifo do autor). Ouviam a palavras de ordem contra os ditos “fraccionistas". Papy Bolingô não se conformava com o que ouvia: "Não foi para isto que fizemos a Independência.

\footnotetext{
${ }^{2}$ Chácara, sítio.
} 
Não para que os angolanos se matassem uns aos outros como cães raivosos" (AGUALUSA, 2012, p. 59). A crítica de Papy Bolingô a toda essa turba persecutória vem com algumas frases simples de esperança: "Pode levar muito tempo até a confusão passar. Vais passar, camarada. A maldade também precisa descansar" (AGUALUSA, 2012, p. 59). Através das desventuras de Pequeno Soba, dentro e fora da prisão nos deparamos com a realidade desses ambientes. Se “a arte pós-modernista é exatamente aquilo que funde contradições do modernismo num enfoque explicitamente político" (HUTCHEON, 1991, p. 44), essa relevância das ideologias políticas para a construção das identidades do romance e para as relações entre as personagens compõe um ambiente de leitura crítica compatível com aquele de uma metaficção historiográfica.

A vida de Ludo se inter-relaciona com as vidas das outras personagens seja como mera testemunha da história, por exemplo, quando de seu terraço ela acompanha o início da guerra civil, ou quando ela assiste à perseguição de Pequeno Soba, no dia 27 de maio de 1977. Ainda, seja quando assiste o resgate de Papy Bolingô, seja como agente da história, quando se torna responsável pelo enriquecimento de Pequeno Soba ao soltar o pombo-correio com a mensagem de amor, que era de Monte (agente do governo recém-eleito), e os diamantes usados na arapuca, no papo.

Monte, como representante da ordem legítima instituída pelo governo eleito do MPLA, é o responsável pelas ações mais horrendas e bárbaras do enredo. Fuzila Jeremias, prende Madalena por ter ajudado o mercenário a se curar e a fugir, tortura Pequeno Soba na prisão, ou seja, é a representação da barbárie empenhada pelo governo totalizante. "O que ele [o pós-modernismo] faz é dar ao modernismo uma interpretação livre, ele 'o examina criticamente, procurando descobrir suas glórias e seus erros"” (PORTOGHESI, 1982, p. 28 apud HUTCHEON, 1991, p. 52). Com base nessa afirmação, podemos deduzir que o romance empenha um desafio crítico, livre de julgamentos, manifesto inclusive no episódio que narra a morte de Monte, que não foi vítima de suas ações cruéis realizadas em nome do sistema, mas da queda de uma antena parabólica sobre a sua cabeça. No rastro deixado por Monte, encontramos ainda a falsificação de lendas, como narrado no capítulo "Onde se esclarece um desaparecimento (quase dois), ou de como, citando Marx, tudo que é sólido desmancha no ar", que revela o assassinato encomendado de Daniel Benchimol. Contudo, Monte é uma referência importante para o romance, pois colabora diretamente para a multiplicidade de pontos-de-vista do romance, o que é mais uma característica de uma metaficção historiográfica, pois nela “[...] não há nenhuma pretensão de mimese simplista. Em vez disso, a ficção é apresentada como mais um entre os discursos pelos quais elaboramos nossas 
versões da realidade, e tanto a elaboração como sua necessidade são o que se enfatiza no romance pós-modernista" (HUTCHEON, 1991, p. 64).

A personagem Daniel Benchimol carrega consigo, mais notavelmente, a crítica do narrador às lacunas na história de Angola. $\mathrm{O}$ jornalista é um colecionador de desaparecimentos, suas ações como repórter investigativo permitem-no ter esse hobby. Junto com a apresentação dessa personagem há a descrição de alguns desaparecimentos acontecidos em território angolano, como, por exemplo, o desaparecimento de um Boeing 747 russo, sobre o qual as autoridades russas cobram explicações até o presente. É esse personagem, também, que vai investigar o paradeiro de Ludovica, a pedido de sua filha, que está a procurála. O fato é que, por conta da busca de Daniel pelos aviões comerciais desaparecidos, Monte fora designado para matá-lo, porém a ação destinada a acontecer no lodge 6, onde Daniel estava hospedado, aconteceu no lodge 9 (o número se soltou e virou de ponta-cabeça). Esse engano ocasionou na morte do escritor francês Simon-Pierre Mulamba. Monte precisou intervir diretamente na cena do crime e limpar a confusão do cúmplice; foi, então, até o bar em que Simon-Pierre esteve por último, jogou o chapéu de feltro do escritor no chão e acordou, frenético, o jovem Baiacu, que dormia perto do local, para alertá-lo: "Ali, onde tem um chapéu! Estava um mulato alto, a mijar, e então, de repente, a terra engoliu-o. Só ficou o chapéu" (AGUALUSA, 2012, p. 119). Esse "acontecimento" é uma forma de criticar o governo totalizante, que fabrica fatos extraordinários para explicar suas ações de Estado. Segundo Linda Hutcheon, um poder totalizante é aquele que busca "unificar e organizar (e atenuar) quaisquer contradições a fim de coaduná-las" (HUTCHEON, 1991, p. 12). Dessa forma, é possível entender que esses governos se aproveitam da credulidade das pessoas para encobrir suas ações. "A problematização pós-moderna se volta para nossas inevitáveis dificuldades em relação à natureza concreta dos acontecimentos (no arquivo só conseguimos encontrar seus vestígios textuais para transformar em fatos) e sua acessibilidade" (HUTCHEON, 2012, p. 161).

Com diamantes no papo e a carta de amor presa à pata, o pombo-correio tão decisivo para a vida de Pequeno Soba foi solto pelas mãos de Monte. Ele utilizava aquele pombo, chamado Amor, para marcar o encontro decisivo com sua namorada e, por final, esposa, para que pudessem fugir do pai dela, que queria separá-los. Ludovica caçou esse pombo-correio usando pedras de diamantes como isca e após encontrar a carta de amor presa ao pombo decide soltá-lo, sem imaginar que esse pombo mudaria a vida de Pequeno Soba, a ponto de ele comprar o apartamento ao lado daquele em que ela morava. Essa série de coincidências, inter-relacionadas, reforça a ideia de que a realidade se constitui a partir das ações individuais 
dos sujeitos. Ao revelar-se a dependência dos "acontecimentos" de cada uma das personagens, o como cada uma dessas personagens é importante para o futuro da outra, o narrador busca incutir no leitor uma crítica sobre a importância da subjetividade na construção da história.

\section{As identidades pós-modernas e as personagens do romance}

As personagens do romance Teoria geral do esquecimento encontram-se deslocadas intencionalmente do centro das referências políticas e históricas de Angola. Elas estão numa situação "inevitavelmente identificado[as] com o centro ao qual aspira[m], mas que lhe[s] é negado[a]" (HUTCHEON, 1991, p. 88) porque são constituídas a partir da história angolana, mas encontram-se à margem dela, por contingência ou vontade. Essas personagens, enquanto caracterizadas como personagens "ex-cêntricas" ou "off-centro" ajudam na constatação desse romance como uma metaficção historiográfica. Como uma obra pós-modernista, a construção dessas personagens do romance, portanto, pode ser analisada pela perspectiva dos descentramentos das identidades pós-modernas, como sintetizado por Stuart Hall em A identidade cultural na pós-modernidade (2011).

Como proposta de uma reconstituição dos vinte e oito anos em que a protagonista esteve trancada em uma cobertura em Luanda, o romance explora ao máximo as vicissitudes da personagem Ludovica Fernandes Mano. Quando o leitor encontra no meio das suas descrições a informação de que ela, após sofrer um estupro e engravidar, fora obrigada a entregar a criança para adoção por ser, ela mesma, uma criança ainda, podemos reconhecer um grande trauma, que o narrador chama de "O Acidente" e que aproxima a análise da personalidade dessa personagem pela perspectiva patológica do comportamento. Hall explica que:

A teoria de Freud de que nossas identidades, nossa sexualidade e a estrutura de nossos desejos são formadas com base em processos psíquicos e simbólicos do inconsciente, que funciona de acordo com uma "lógica" muito diferente daquela da Razão, arrasa com o conceito do sujeito cognoscente e racional provido de uma identidade fixa e unificada [...] (HALL, 2011, p. 36$37)$.

Portanto, as experiências passadas da personagem compõem e dialogam com as suas identidades, como, por exemplo, a agorafobia de Ludovica (medo severo de lugares abertos), que não é nada muito severo, posto que não impede o amadurecimento do seu intelecto, e é determinante para a composição da identidade da personagem durante o resto da história. 
“Após a morte dos pais ficou a viver em casa da irmã. Raramente saía, ganhava algum dinheiro lecionando português a adolescentes entediados. Além disso, lia, bordava, tocava piano, via televisão, cozinhava" (AGUALUSA, 2012, p. 11). Assim, a constatação de que as ações do inconsciente da personagem estão presentes na constituição dessa identidade pode indicar a utilização do narrador do conhecimento sobre o descentramento das identidades pósmodernas causado pelas teorias psicanalíticas, como apontado por Hall, para a composição dessa personagem.

Ludovica, então, muda-se para Luanda com a irmã, Odete, após o casamento desta com o engenheiro de minas, Orlando Pereira dos Santos, pouco antes da Revolução dos Cravos (1974) e da independência de Angola (1975). Ludo, como é chamada no decorrer da história, vê-se obrigada a sair da metrópole colonial para viver e servir à sua irmã na "colônia africana". Essa partida é o segundo trauma na vida da portuguesa, que a obriga a uma reconfiguração do seu pensar, do seu sentir e do seu falar:

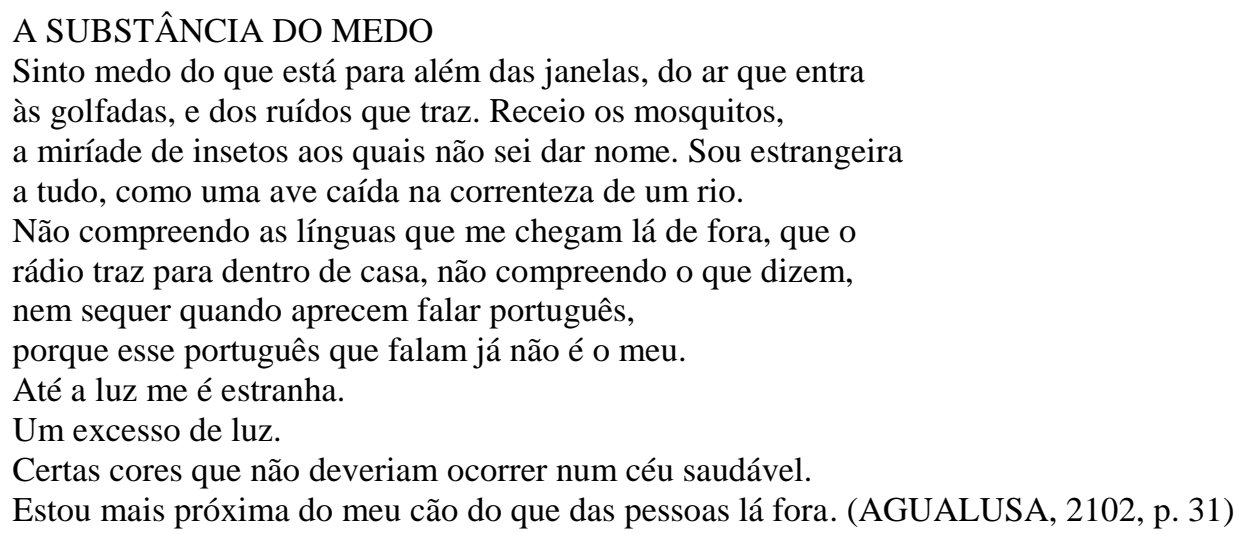

Esse "trauma" pode ser explicado a partir de um deslocamento da personagem dentro da própria língua. Abandonar o português da "metrópole" para ser obrigada a viver o português da "colônia" aproxima o leitor da ideia de que

\footnotetext{
A língua é um sistema social e não um sistema individual. Ela preexiste a nós. Não podemos, em qualquer sentido, ser seus autores. Falar uma língua não significa expressar nossos pensamentos mais interiores e originais; significa também ativar a imensa gama de significados que já estão embutidos em nossa língua e em nossos sistemas culturais. (HALL, 2011, p. 40)
}

Hall fez essa afirmação a partir do entendimento de que os ensinamentos de Ferdinand de Saussure e de Jacques Lacan são definitivos para a compreensão da instabilidade dos significados, tal qual as identidades na pós-modernidade, que variam de acordo com as premissas e as proposições, que a interpretação da língua permite. Dessa forma, o 
descentramento saussuriano e lacaniano encontra-se presente na composição dessa personagem. Em Angola, tudo parece diferente aos olhos da portuguesa, mas Orlando, o cunhado, e Odete, a irmã, até conseguem estabelecer uma rotina semelhante à antiga rotina de Ludo, para acomodar a sua ansiedade.

Porém, um dia o casal some, não volta mais para casa. Ludo se vê, então, em regime de urgência. Inclusive há uma tentativa de assalto ao apartamento e ela mata um dos supostos agressores. Nesse momento a personagem impõe-se uma pena por sofrer esse terceiro trauma; e a uma nova reconfiguração da sua realidade. Ela ergue um muro bloqueando a entrada do corredor para o apartamento. Uma clara demonstração de medo pelo "poder disciplinar" a que seria submetida; uma tentativa dúbia de autopreservação. A presença do "poder disciplinar" na composição da identidade dessa personagem, remete à obra de Foucault, que, como escreve Hall, é outro descentramento presente na constituição das identidades pós-modernas.

Ludo precisou aprender, no isolamento, que o amor pela terra que seu cunhado tinha é um sentimento que se vive na plenitude das relações com a paisagem, com as pessoas e com todas as culturas que compõe a nação angolana. Esses pensamentos da personagem ganham vida e voz através de sua escrita e da reconstituição da sua história.

\section{A CEGUEIRA}

(E OS OLHOS DO CORAÇÃO)

Venho perdendo a vista. Fecho o olho direito e já só enxergo

Sombras. Tudo me confunde. Caminho agarrada às paredes.

Leio com esforço, e apenas sob a luz do sol, servindo-me de

Lupas cada vez mais fortes. Releio os último livros, os que me recuso a queimar. Andei queimando as belas vozes que me acompanharam ao longo de todos estes anos.

Às vezes penso: enlouqueci.

Vi, do terraço, um hipopótamo dançando na varanda do andar ao lado. Ilusão, bem sei, mas ainda assim vi-o. Pode ser fome. Tenho-me alimentado muito mal.

A fraqueza, a vista que se esvai, isso faz com que tropece nas letras, enquanto leio. Leio páginas tantas vezes lidas, mas elas são já outras. Erro, ao ler, e no erro, por vezes, encontro incríveis acertos. No erro me encontro muito. Algumas páginas são melhoradas pelo equívoco.

Um fulgor de pirilampos pirilampeia pelos quarto. Movo-me Como uma medusa, nessa bruma iluminada. Afundo-me nos meus próprios sonhos. Talvez a isto se possa chamar morrer. Fui feliz nesta casa, certas tardes em que o sol me visitava na cozinha. Sentava-me à mesa. Fantasma vinha e pousava a cabeça no meu regaço.

Se ainda tivesse espaço, carvão e paredes disponíveis, poderia escrever uma Teoria geral do esquecimento.

Dou-me conta de que transformei o apartamento inteiro num imenso livro. Depois de queimar a biblioteca, depois de eu morrer, ficará só a minha voz.

Nesta casa todas as paredes tema minha boca. (AGUALUSA, 2012, p. 77-78) 
Como uma personagem mulher que se marginaliza, mas que tem a possibilidade de ser ouvida e de desenvolver a consciência sobre a sua importância para outras pessoas, torna-se necessário recolocá-la no centro da história do romance e, consequentemente, no centro do discurso da história. Essa recolocação do discurso feminino e essa crítica à hegemonia dos discursos são reflexos do "impacto do feminismo, tanto como uma crítica teórica quanto como um movimento social" (HALL, 2011, p. 44), sendo, portanto, um argumento referente à "politica da identidade" e ao "descentramento conceitual do sujeito cartesiano e sociológico" (HALL, 2011, p. 45) em direção a uma valorização das diferenças daqueles grupos excluídos ou impedidos de se manifestar até a segunda metade do século $\mathrm{XX}$ - por exemplo, as mulheres, os negros, os estrangeiros, etc. Ludo é a protagonista do romance e são seus escritos que permitem "a reconstituição histórica" dos fatos narrados, sua voz é o centro do discurso.

$\mathrm{O}$ argumento histórico, sempre presente à sombra da narrativa, demonstra como as estruturas macro-políticas influenciam as ações e as experiências vividas pelas personagens. Nenhuma delas está livre das estruturas sociais e políticas instauradas. Elas conduzem as ações de todos os personagens e obrigam-nos inclusive a inter-relacionarem-se, ainda que indiretamente. Revela-se, assim, no argumento do romance, a presença constante do descentramento do sujeito sociológico causado pelas teorias estruturalistas de Louis Althusser (apud HALL, 2011). No caso de Ludo, ela vê-se ilhada pela guerra civil. O massacre toma conta das imediações de Luanda e sua percepção dos eventos é limitada: "Começou um tiroteio. Primeiro disparos isolados e depois o crepitar intenso de dezenas de armas automáticas" (AGUALUSA, 2012, p. 20). Ela é uma testemunha ocular da revolução e da guerra civil e isso a amedronta a tal ponto que conduz suas ações de clausura e autodefesa.

A personagem Sabalu, que se relaciona diretamente com Ludo, apresenta também esses descentramentos pós-modernos, na medida em que, a partir do seu encontro com ela, ele pode recuperar tudo aquilo que o sistema lhe havia negado. No capítulo "Os mortos de Sabalu”, toda a história do menor do interior, que teve sua mãe assassinada e que foge em busca do pai na capital com a ajuda de amigos, ocupa-se descritivamente dos horrores da exploração a que as crianças estão sujeitas nas ruas de Luanda e do sofrimento a que os órfãos de Angola encontram-se submetidos.

Entardecia quando a fome o empurrou até um pequeno bar. Sentou-se receoso. Pediu uma sopa e uma Coca-Cola. Ao sair, um rapaz de rosto inchado, pele muito maltratada, atirou-o contra a parede. 
O meu nome é Baiacu canuco. Sou o Rei do Quinaxixe. Apontou para a estátua de uma mulher, no centro do jardim: Aquela é minha dama. Ela, a Rainha Ginga. Eu, o Rei Gingão. Tens kumbu?

Sabalu encolheu-se, chorando. Dois outros meninos surgiram da sombra, ladeando Baiacu, e impedindo-lhe a fuga. Eram idênticos, baixos, sólidos, como pitbulls, olhos sem luz e um mesmo sorriso absorto nos lábios bem desenhados. Sabalu levou a mão ao bolso e mostrou o dinheiro. Baiacu arrebatou as notas:

Ya, avilo. Foste bem. Esta noite podes cubar connosco, ali nos caixotes. A gente te protege. Amanhã começas a trabalhar. Como te chamas?

Sabalu.

Prazer, Sabalu. Este é o Diogo!

Qual deles?

Os dois. Diogo é os dois! (AGUALUSA, 2012, p. 124)

A lei do mais forte, que domina as ruas de Luanda, pode causar inclusive a perda da identidade, como pode-se pensar ao conhecer a personagem Diogo. Ele não se diferencia, na medida em que se adequa à função de colaborar com o explorador Baiacu. Essa personagem acentua ainda mais o argumento da crítica social, já que a responsabilidade pelo desenvolvimento da personalidade exploradora e violenta se dá a partir de um modelo de dominação e controle, que são anteriores ao aparecimento dessa subjetividade, como atestado pelo pensamento estruturalista marxista. Sabalu conhece Ludo a serviço de Baiacu; ao mandar o menino subir os andaimes para roubar, Baiacu tornou-se o agente catalizador do descentramento social da personalidade de Sabalu. Ao conviver com Ludo, para ajudá-la e para fugir de Baiacu, outros descentramentos estruturais podem ser localizados na estrutura narrativa, como encontra-se expresso na possibilidade de retomada da construção da identidade que Sabalu adquire, a partir de seu reencontro com o aprendizado da língua (descentramento saussuriano):

Sabalu ajudou a velha senhora a erguer-se, levou-as até ao quarto e deitou-a no colchão. Estendeu-se ao lado dela e adormeceu. $\mathrm{Na}$ manhã seguinte, foi ao mercado e regressou carregado de legumes, vegetais, fósforos, sal, temperos vários e dois quilos de carne de vaca. Trouxe também um fogão portátil, desses para campismo, com uma pequena botija de gás butano. Ele mesmo cozinhou, no chão do quarto, seguindo as instruções de Ludo. Comeram ambos com vontade. Depois o menino lavou os pratos e arrumou a loiça. Cirandou pela casa, curioso:

Tens muitos livros, tu.

Muitos livros? Sim, tive muitos livros. Agora são poucos.

Nunca vi tantos.

Sabes ler?

Arrumo mal as letras. Só estudei a primeira classe.

Queres que te ensine? Ensino-te a ler e depois tu lês para mim. (AGUALUSA, 2012, p. 103)

Em uma relação de mútuo benefício, ambas as personagens resgatam algum conforto social e referência autóctone familiar (descentramento freudiano), principalmente quando Sabalu adota Ludo como avó: "Não tenhas medo, avó. Eu te protejo" (AGUALUSA, 2012, p. 
104). A sobrevivência de ambos dependia dos andaimes colocados até a altura da cobertura; quando estes são retirados, Sabalu é quem ajuda Ludo a vencer o desafio de derrubar a parede que ela construíra há tanto tempo, aquela prisão auto-infringida que ela achava que garantia a sua liberdade é o que revela a presença do descentramento foucaultiano, porque Sabalu permite a Ludo reintroduzir-se ao sistema e à realidade:

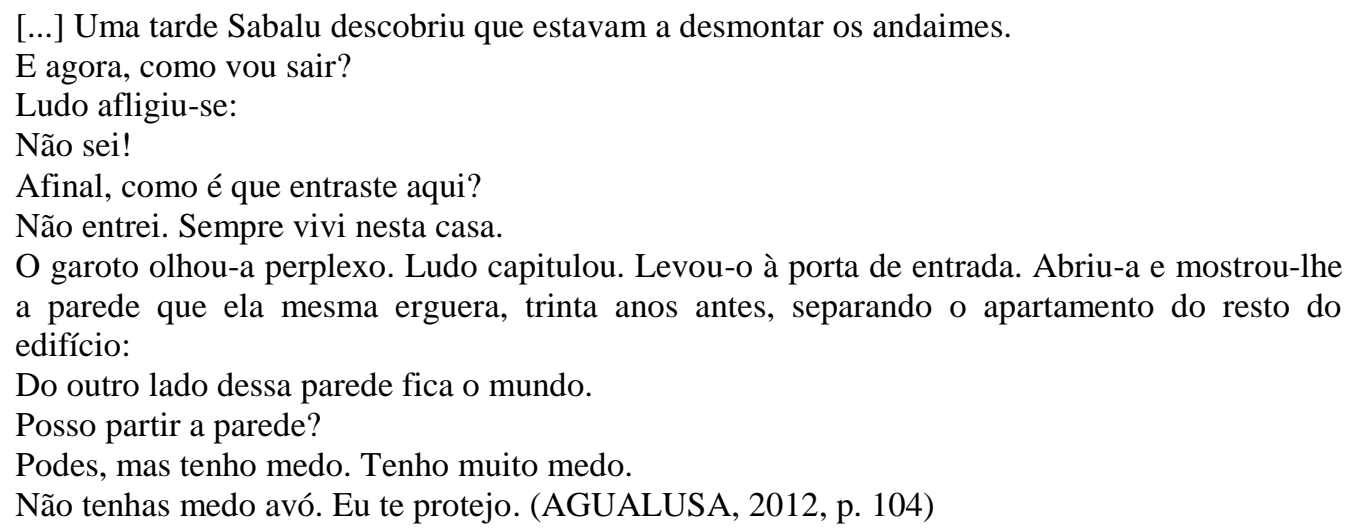

Sabalu alcança a possibilidade de inferir sua própria subjetividade à história, já que é ele quem entrega os diários de Ludo para o narrador (descentramento hegemônico do discurso político). Sabalu, portanto, desenvolve uma relação simbiótica com Ludo, que modifica o estilo de vida de ambos (descentramento marxista) o que, novamente, sugere a presença dos complexos descentramentos responsáveis pela construção das identidades pós-modernas. Como um menor de rua, um órfão e uma criança adotada, Sabalu tem ainda potencial de representação desses grupos, que em nenhum momento tiveram acesso ao registro de suas ações na História canônica, o que os conduzem, portanto, à margem desse tipo de discurso.

Ludo é a personagem centralizadora da transformação de alguns destinos, que, por sua vez, interagem com outras personagens, que se modificam com esses encontros e assim sucessivamente. De certa forma, todas elas têm potencial para representar vozes marginais específicas da sociedade angolana. Vozes essas produzidas dentro do contexto pós-moderno, e que são expressão da contemporaneidade, afinal, essas presenças, numa reconstituição, aparecem porque, em algum momento, foram percebidas nos vestígios e nas reminiscências da memória da protagonista.

\section{Considerações finais}

Teoria geral do esquecimento, de José Eduardo Agualusa, é uma metaficção 
historiográfica e, como tal, coloca-se a questionar, ficcionalmente, as lacunas históricas, através da reconstituição da história de diversas personagens, além de rever eventos históricos consagrados pelo discurso historiográfico oficial por um prisma ex-cêntrico. A vida cotidiana dessas personagens é diretamente influenciada pelos conflitos do povo angolano. Ainda assim, as histórias dessas personagens estão imbricadas a vários contextos ideológicos da pósmodernidade. A partir da perspectiva pós-modernista da obra, é possível localizar no estudo de Stuart Hall algumas dessas estratégias de representação das personagens, que acabam por exaltar a variedade e a multiplicidade de valores da cultura angolana.

A presença de personagens ex-cêntricas, na construção dos "acontecimentos" ficcionais, derivados dos fatos históricos relacionados com a luta pela independência e com a guerra civil, revela uma crítica da realidade histórica a partir da ficção. Essas personagens apresentam, na sua construção, aspectos relativos aos principais descentramentos das identidades culturais da pós-modernidade, o que pode ajudar a entender como as diversas subjetividades angolanas têm buscado resistir aos séculos de colonização e globalização, a fim de incutir no leitor um pensamento crítico sobre a importância das subjetividades na construção de um presente mais solidário.

\section{Referências}

ABADALA JR., Benjamin. Literatura, história e política: literaturas de língua portuguesa no século XX. Cotia: Ateliê Editorial, 2007.

AGUALUSA, José Eduardo. Estação das chuvas. Alfragide: D. Quixote, 1996. O vendedor de passados. Rio de Janeiro: Gryphus, 2011.

. Teoria geral do esquecimento. Rio de Janeiro: Foz, 2012.

BARTHES, Roland. O efeito de real. In: MENDONÇA, Antônio Sérgio et al. (Org.). Literatura e semiologia: pesquisas semiológica. Petrópolis: Vozes, 1972.

BEZERRA, Ana Cristina. Tessitura da memória em O vendedor de passados de José Eduardo Agualusa. 2013. Dissertação (Mestrado em Letras) - Universidade Federal do Rio Grande do Norte, Natal, 2013. Disponível em: <http://repositorio.ufrn.br:8080/jspui/handle/1/8354>. Acesso em: 21 maio 2015.

CANDIDO, Antonio. Literatura e sociedade. Rio de Janeiro: Ouro sobre Azul, 2006.

COUTO, Mia. Pensatempos: textos de opinião. Maputo: Ndjira, 2005. 
HALL, Stuart. A identidade cultural na pós-modernidade. 11. ed., Rio de Janeiro: DP\&A, 2011.

HUTCHEON, Linda. Poética do pós-modernismo: história, teoria, ficção. Rio de Janeiro: Imago, 1991.

LEJEUNE, Philippe. O pacto autobiográfico: de Rousseau à Internet. Organização de Jovita Maria Gerheim Noronha. Tradução de Jovita Maria Gerheim Noronha e Maria Inês Coimbra Guedes. Belo Horizonte: UFMG, 2008.

PESTANA, Nelson. A história na estória em Angola: Henrique Abranches e José Eduardo Agualusa. In: CHAVES, Rita; MACÊDO, Tânia. (Orgs.). Marcas da diferença: as literaturas africanas de língua portuguesa. São Paulo: Alameda, 2006. p. 227-241.

SANTIAGO, Silviano. O entre-lugar do discurso latino-americano. In: Uma

Literatura nos Trópicos: ensaios sobre dependência cultural. São Paulo: Perspectiva, 1978. p. 9-27.

STACUL, Juan Filipe. Um homem em busca de memória, um povo em busca de identidade: as relações entre literatura e história no romance $\mathrm{O}$ Vendedor de Passados, de José Eduardo Agualusa. Letras, Curitiba, n. 82, p. 261-276, 2010. Disponível em:

<http://ojs.c3sl.ufpr.br/ojs/index.php/letras/article/download/25088/16785>. Acesso em: 21 maio 2015.

VISENTINI, Paulo Fagundes. As revoluções africanas: Angola, Moçambique e Etiópia. São Paulo: UNESP, 2012. 